Review

\title{
Does crotalaria (Crotalaria breviflora) or pumpkin (Cucurbita moschata) inter-row cultivation in restoration plantings control invasive grasses?
}

\author{
Ricardo Gomes César ${ }^{1}$, Pedro Henrique Santin Brancalion ${ }^{1 *}$, Ricardo Ribeiro Rodrigues², Aretha Medina dos Santos Oliveira ${ }^{3}$, \\ Marcelo Corrêa Alves ${ }^{4}$
}

${ }^{1}$ USP/ESALQ - Depto. de Ciências Florestais, Av. Pádua Dias, s/n - 13418-900 - Piracicaba, SP - Brasil.

2USP/ESALQ - Depto. de Ciências Biológicas.

${ }^{3}$ Fundação S.O.S. Mata Atlântica, Rod. Marechal Rondon, km 118,3 - Fazenda São Luis - 13300-000 - Itu, SP - Brasil.

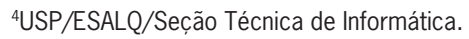

*Corresponding author <pedrob@usp.br>

Edited by: Daniel Scherer de Moura

\begin{abstract}
Alternative methods to control invasive fodder grasses are necessary to reduce the use of herbicides in forest restoration, which has been carried out primarily in riparian zones. We sought to investigate if inter-row cultivation of crotalaria (Crotalaria breviflora DC) or pumpkin (Cucurbita moschata Duschene ex. Poir) with native tree species is an efficient strategy to control invasive fodder grasses in restoration plantings. We tested five treatments in a randomized block design, namely (1) control of brachiaria grass (Urochloa decumbens (Stapf.) Webster) with glyphosate in the implementation and post-planting grass control of the reforestation, (2 and 3 ) glyphosate use in the implementation and inter-row sowing of crotalaria (2) or pumpkin (3), and control of brachiaria by mowing in the post-planting phase, (4 and 5) mowing in the implementation and inter-row sowing of crotalaria (4) or pumpkin (5), and control of brachiaria by mowing in the post-planting phase. Post-planting grass control was carried out four and nine months after tree seedling planting. Throughout 13 months, we evaluated the percentage of ground cover by brachiaria grass, pumpkin production, and native tree seedling mortality, height and crown cover. The exclusive use of glyphosate, without inter-row sowing of pumpkin or crotalaria showed the most favorable results for controlling brachiaria grass and, consequently, for tree seedling development. Hence, inter-row cultivation of green manure or short-lived crop species is not enough to control invasive grasses in restoration plantings, and complementary weeding is necessary to reduce the highly competitive potential of $\mathrm{C} 4$ grasses for supporting native species seedlings growth.
\end{abstract}

Keywords: forest restoration, green manuring, inter-row cultivation, native species reforestation, grass control
Received February 29, 2012

Accepted December 18, 2012
Hooper et al., 2005). Therefore, the control of such grasses is crucial for the success of restoration projects around the world.

In Brazil, forest restoration efforts have been concentrated in riparian zones, due to their legal protection as Permanent Preservation Areas (PPA) by the Brazilian Forest Act, which prohibits land use in this condition for economic activities (Rodrigues et al., 2011). As a result of the environmental vulnerability of riparian areas (Relyea, 2005; Thompson et al., 2006) and risks for water contamination (Blanchoud et al., 2007), the use of herbicide in forest restoration has been the subject of ongoing debate and has raised several concerns. On the other hand, herbicide use, especially of glyphosate, enhances weed control in ecological restoration efforts (Ansley and Castellano, 2006; Carlson and Gorchov, 2004; Cornish and Burgin, 2005). While there is no consensus on the use of herbicides in riparian areas as a safe strategy of weed control in forest restoration, alternative, non-chemical methods of weed control are especially demanded and necessary (Pywell et al., 2010). Following this trend, in Brazil, legal instruments have allowed inter-row cultivation of green manures and short-lived crops with native tree species, such as the São Paulo state environmental office (SMA) resolution $\mathrm{n}^{\circ} 8$ of 2008 . 
In Brazil, the inter-row cultivation of green manure species in restoration plantings has been recommended primarily because of its favorable results in orchards (Walker and Morey, 1999) and agroforestry systems (Nair, et al., 1984). Additionally, it may also benefit the restoration process by ameliorating the soil, which is frequently degraded in sites where restoration will be carried out (Chazdon, 2012). The other possibility - inter-row cultivation of crop species - has been indicated as an alternative for reducing the costs of restoration plantings (Vieira et al., 2009), which are normally higher than 5,000 US\$ ha ${ }^{-1}$ in Brazil (Rodrigues et al., 2011).

In this context, we sought to investigate if interrow cultivation of crotalaria (Crotalaria breviflora DC) or pumpkin (Cucurbita moschata Duschene ex. Poir) with native tree species is an efficient strategy to control invasive fodder grasses in restoration plantings.

\section{Materials and Methods}

\section{Study area}

This study was carried out from Dec. 2008 to Dec. 2009 at Itu, state of São Paulo, Brazil, southeastern Brazil (23 $14^{\prime} 2^{\prime \prime} \mathrm{S} ; 47^{\circ} 24^{\prime} 35^{\prime \prime} \mathrm{W} ; 540 \mathrm{~m}$ a.s.1.). This region has a Cwa climate according to the Köppen classification, characterized by rainy and warm summers and cold and dry winters, with a mean annual temperature of 21.5 ${ }^{\circ} \mathrm{C}$. Temperatures during this study were very similar to historical weather data and precipitation differed only in three of the 13 months of this study (Figure 1).

The study area is located within the Atlantic Forest Biome, specifically in the Seasonally Dry Forest. Soils in the area of study belong to the Ustults, which are characterized as having a low content of organic carbon and periods of low and high moisture. The farm where the experiment was carried out was formerly used for coffee (Coffea arabica L.) production in the early $20^{\text {th }}$ century, and it was later converted to pasturelands of Urochloa decumbens (Stapf.) Webster (hereafter brachiaria) for intensive cattle ranching. As a result of historical and intensive land use, the resilience of the study area was compromised, and native tree seedlings are no longer found regenerating in the field. Consequently, plantation of native tree seedlings has been used as the main restoration method in this farm.

\footnotetext{
Strategies for controlling brachiaria grass in native tree species reforestation

Crotalaria (Crotalaria breviflora) and pumpkin $(\mathrm{Cu}$ curbita moschata) were chosen as model species of green manuring and short-lived crop species, respectively. Crotalaria is a genus widely used as green manure in orchards and crop rotations in Brazil, as are many other Leguminosae around the world, while the Cucurbita genus can grow in adverse condition and is important for the subsistence of small farmers. Both species were planted in Dec. 2008, one week before native tree seedling planting.
}

Glyphosate was selected for the experiment because it is the most used herbicide in forest restoration efforts in Brazil, as well as in other countries. Crotalaria, pumpkin, and glyphosate were used in different experimental designs for testing particular strategies for grass control in native tree species plantings (Table 1). Five treatments were evaluated in a randomized block design, with four replicates per treatment. Each plot was $12 \times 18 \mathrm{~m}\left(216 \mathrm{~m}^{2}\right)$, but after discounting part of the border of the plot, the effective plot area was $96 \mathrm{~m}^{2}$. All plots had $100 \%$ grass coverage before treatments were established.

Invasive grasses were suppressed with herbicide or mowing 15 days before native tree planting and one week before inter-row cultivation of crotalaria or pumpkin. The effect of crotalaria and pumpkin on brachiaria control was only evaluated for four months after planting (Table 1), as those species were cut altogether with brachiaria mechanical control. They were cut at this time because crotalaria individuals were already flowering, and pumpkins were bearing ripe fruits. The evaluations carried out after this period were used to determine if the biomass from crotalaria or pumpkin cut had any negative effect on brachiaria coverage.
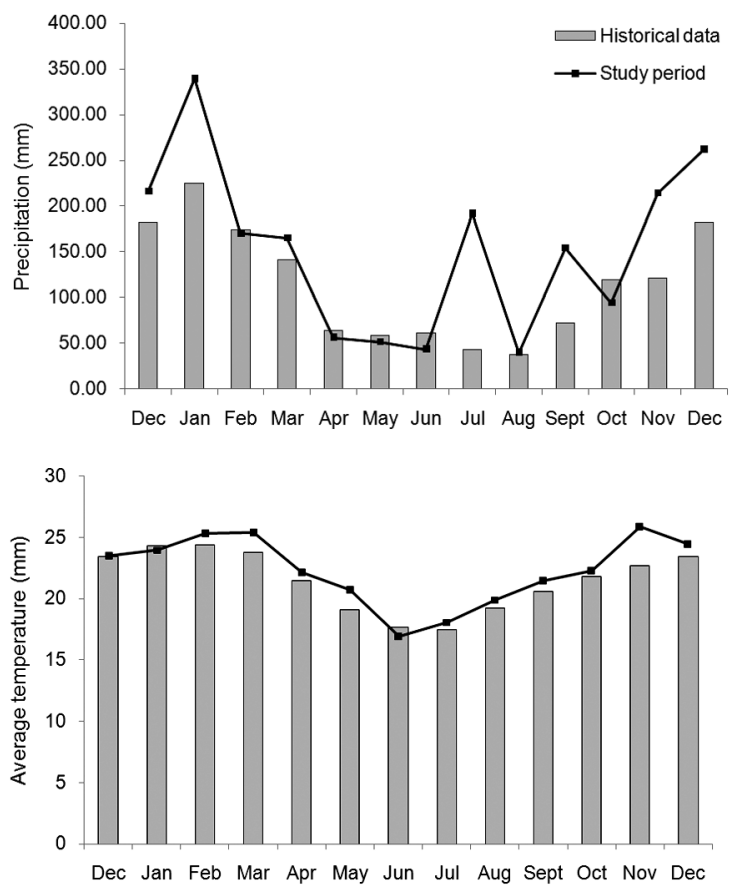

Figure 1 - Climatic information of the area during the study period and historical weather data. Historical weather data refers to the city of Itu, state of São Paulo, Brazil, where the experiment was carried out, while study period data was gathered from the closest meteorological station, $35 \mathrm{~km}$ from the study area. Sources: INMET (Brazilian National Institute of Meteorology) and Cepagri (Center of Meteorological and Climatic Research for Agriculture). 
Table 1 - Strategies for controlling the invasive fodder grass brachiaria in native tree species reforestation in Itu-SP, southeastern Brazil.

\begin{tabular}{lccc}
\hline Treatments & $\begin{array}{c}\text { Brachiaria control before tree planting } \\
\text { (start of the first month) }\end{array}$ & Inter-row cultivation & Brachiaria control (after four and nine months) \\
\hline 1 & spraying glyphosate in the total area & none & glyphosate spraying \\
2 & spraying glyphosate in the total area & crotalaria & mowing of both brachiaria and crotalaria \\
3 & spraying glyphosate in the total area & pumpkin & mowing of both brachiaria and pumpkin \\
4 & mowing in the total area & crotalaria & mowing of both brachiaria and crotalaria \\
5 & mowing in the total area & pumpkin & mowing of both brachiaria and pumpkin \\
\hline
\end{tabular}

The field activities involved in the implementation of this experiment are described below:

- Control of leaf-cutter ants: we distributed $10 \mathrm{~g}$ of sulfluramid-treated granular baits in the nest openings found in the experimental area and in its surroundings at the time of reforestation and in intervals of two months after planting.

- Glyphosate spraying: Glyphosate was diluted in water in the proportion 1:100, and $1 \%$ of urea was mixed in the solution. Glyphosate was sprayed by tractor with a $3 \mathrm{~m}$ spraying bar in the implementation of the experiment (one week before inter-row cultivation and 15 days before tree seedling planting) in treatments 1,2 and 3, and four and nine months after the beginning of evaluations in treatment 1 . Herbicide was applied using a coastal sprayer with a "Napoleon hat" in the spray nozzle, and seedlings were protected with PVC pipes to prevent drift in the post-planting weed control of the reforestation (treatment 1).

- Mowing: Mowing was accomplished by tractor one week before inter-row cultivation and 15 days before tree seedlings planting, in treatments 4 and 5. In the post-planting grass control phase in treatments $2,3,4$ and 5, brachiaria was controlled by mowing, using brush cutters, four and nine months after tree seedling planting.

- Native tree seedlings planting: before inter-row cultivation, $70 \mathrm{~cm}$ depth planting lines were opened with a tractor by using a subsoiler. Subsequently, we removed with a hoe all the weeds in a radius of $50 \mathrm{~cm}$ around the point of planting. In the effective experimental area, 23 nursery-grown native tree seedlings produced in $56 \mathrm{~cm}^{3}$ plastic tubes were planted $\left(1,666\right.$ seedlings ha ${ }^{-1}, 3 \mathrm{~m} \times 2$ $\mathrm{m}$ spacing). Within each plot, we planted three seedlings of each of the fast-growing, wide canopy species Enterolobium contortisiliquum (Vell.) Morong (Fabaceae), Senna multijuga (Rich.) H. S. Irwin \& Barmeby (Fabaceae), Bauhinia forficata Link (Fabaceae), and Rhamnidium elaeocarpus Reissek (Rhamnaceae); two seedlings of Cedrela fissilis Vell. (Meliaceae), Cecropia pachystachya Trec. (Urticaceae), Hymenaea courbaril L. (Fabaceae), Parapiptadenia rigida (Benth.) Brenan (Fabaceae), and Ficus insipida Willd. (Moraceae); and one seedling of Copaifera langsdorffii Desf. (Fabaceae). This proportion of individuals per species, and their distribution in the field, was based on the proposal of Rodrigues et al. (2009), which grouped native tree species into either filling or diversity groups.

- Crotalaria sowing: We made five sowing lines, spaced $0.5 \mathrm{~m}$ from each other, between every two consecutive planting lines of native tree seedlings ( $3 \mathrm{~m}$ wide), with a density of $15 \mathrm{~kg}$ of seeds ha- ${ }^{-1}$, commonly used for this green manure (treatments 2 and 4). Sowing lines were around $5 \mathrm{~cm}$ deep and were made manually using hoes, seeds were put manually in the lines, with a fine layer of earth over them. Sowing was carried out in Nov. 2008, one week before seedling planting and the beginning of evaluations.

- Pumpkin sowing: We used the spacing of $3 \times 2 \mathrm{~m}(2.5$ $\mathrm{kg}$ of seeds ha ${ }^{-1}$ ) for sowing pumpkin between every two consecutive planting lines of native tree seedlings (treatments 2 and 4). Sowing was carried on by piercing the soil with manual seeders and covering with a fine layer of earth. In this case we reduced the spacing of $3 \times 3$ $\mathrm{m}$ commonly used for commercial pumpkin plantations hoping to cover invasive grasses faster. Sowing was carried out in Nov. 2008, one week before seedling planting and the beginning of evaluations.

\section{Evaluations and data analysis}

- Ground cover by brachiaria grass: Ground cover was estimated by using a $1 \times 1 \mathrm{~m}$ wooden frame subdivided into 25 smaller squares, using four randomly distributed sampling points per plot. The percentage of ground cover by brachiaria grass was obtained by counting the number of squares filled with grass. In order to estimate the mean grass cover of the plot we allocated two sampling points between planting lines and between seedlings in each plot, which were merged in the analysis because they did not differ statistically. The evaluations were carried out monthly in two periods: i) before the first post-planting weed control, in the first four months; and ii) from the first post-planting weed control to the following four months. The mean grass cover of these periods, considering the data obtained each month, was used in the statistical analysis.

- Native tree seedling mortality: Native tree seedling mortality was evaluated in intervals of four months starting in the first month after planting. We considered as dead 
seedlings without leaves and with a dry stem (the inner bark was not green after scraped). After thirteen months, we calculated the overall seedling mortality of each plot.

- Native tree seedling height: Native tree seedling height was evaluated in intervals of four months, beginning in the first month after planting, based on the vertical distance from the seedling base to its upper apical bud. After thirteen months, we calculated the overall seedling height of each plot.

- Native tree seedling crown diameter: Native tree seedling crown diameter was evaluated in intervals of four months after planting. We measured the distance between the opposite extremities of the crown, parallel and perpendicular to the planting line, and obtained the mean crown diameter of the seedling. After thirteen months, we calculated the overall seedling crown diameter of the plot.

- Pumpkin production: Pumpkin production was evaluated at the third month (treatments 3 and 5), based on the total weight of fruits obtained in each plot.

The mean obtained for grass coverage and seedling crow diameter and height were submitted to repeated measures ANOVA, and results were compared using the Tukey test $(p<0.05)$ with the software SAS $9.2^{\circledR}$.

\section{Results}

In the first month after planting, invasive grass coverage was high but not different $(p<0.05)$ among treatments, showing an average of $22 \%$ ground coverage. Evaluations from the second month to the first maintenance intervention in the fourth month showed treatments 4 and 5 (mowed before crotalaria and pumpkin sowing, respectively), to have greater invasive grass coverage than treatments 1,2 and 3 (Figure 2). In this evaluation, values averaged from $75 \%$ grass coverage for mowed treatments to $21.25 \%$ for treatments were herbicide was applied.

In the fifth month after planting, one month after maintenance intervention (mowing in treatments 2, 3, 4 and 5 and herbicide spraying in treatment 1), treatments 1 and 3 had lower invasive grass coverage when compared to other treatments (Figure 2). Nevertheless, in the next months, treatment 1 (no inter-row planting and herbicide spraying during seedling planting and maintenance) had lower grass coverage $(p<0.05)$ than all other treatments, which did not differ among themselves $\left(\mathrm{F}_{4,19}=13.91, p<\right.$ $0.0001)$. In the eighth month after planting, grass coverage averaged at $24 \%$ for treatment 1 and $86 \%$ for other treatments (Figure 2). Although treatment 1 differed greatly from the other treatments in invasive grass coverage, tree seedling mortality did not differ among treatments $\left(\mathrm{F}_{3,19}\right.$ $=1.53, p=0.19)$. Surviving tree seedling height $\left(\mathrm{F}_{3,19}=\right.$ $10.61, p<0.0001)$ and crown diameter $\left(\mathrm{F}_{3,19}=24.63\right.$, $p<0.0001)$ differed only at the end of the studied pe- riod, in the ninth month, when treatment 1 had higher values than all other treatments (Figure 3). The similar
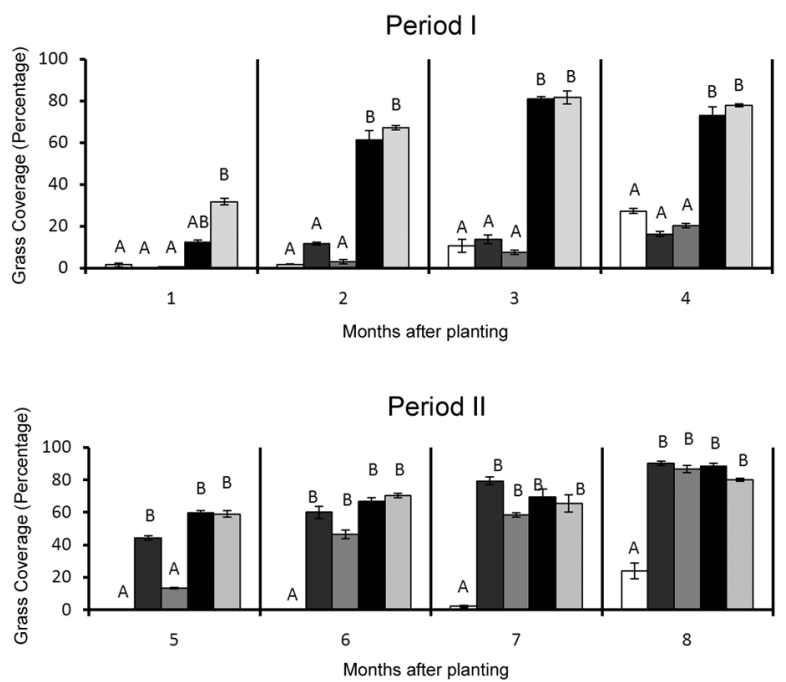

$\square$ Herbicide $\square$ Crotalaria and Herbicide $\square$ Pumpkin and herbicide Crotalaria $\square$ Pumpkin

Figure 2 - Monthly grass (Urochloa decumbens) coverage percentage during the evaluation of crotalaria (Crotalaria breviflora) and pumpkin (Cucurbita moschata) inter-row cultivation in restoration plantings as a strategy for controlling invasive grasses. Period I refers to the four months between planting and post-planting weed control; Period II refers to the four months after the post-planting weed control. Values followed by the same letter do not differ (Tukey, $p<0.05$ ). Data shown are the averages \pm s.e. from four replications.
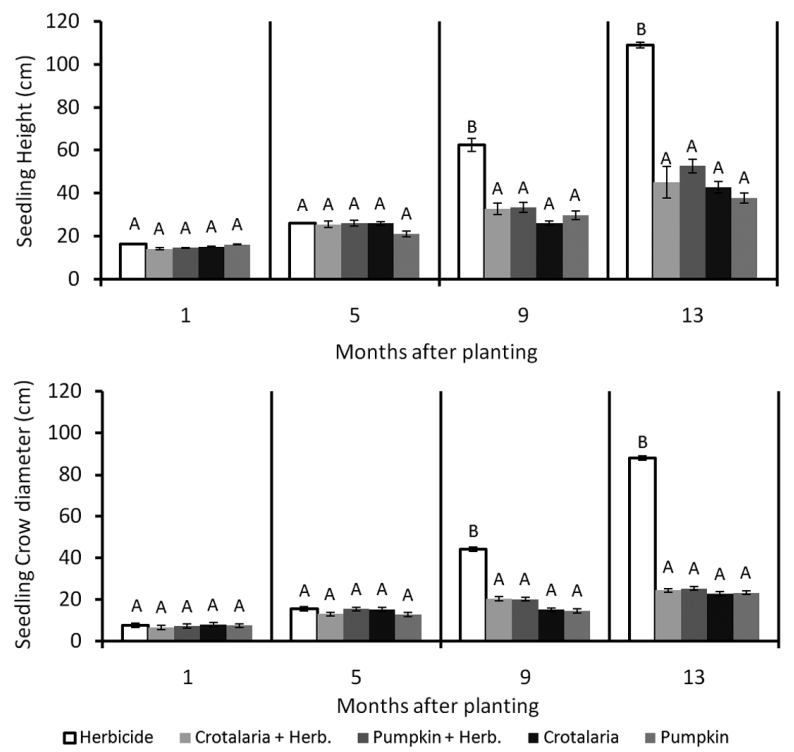

Figure 3 - Average height and crown diameter of the surviving seedlings at one, five, nine and 13 months after planting. Values followed by the same letter do not differ (Tukey, $p<0.05$ ). Data shown are the averages \pm s.e. from four replications. 
height and crown size of tree seedling $(p<0.05)$ in the first month after planting demonstrates that differences in these parameters were due to the effect of treatments and not to initial differences in plant size.

Pumpkin harvesting in treatment 3 (glyphosate spraying before tree seedling planting and pumpkin sowing) resulted in a yield of $29.46 \mathrm{~kg}$ per plot (341 kg $\mathrm{ha}^{-1}$ ), while in treatment 5 (mowing before planting and pumpkin sowing) only $1.81 \mathrm{~kg}$ per plot $\left(28 \mathrm{~kg} \mathrm{ha}^{-1}\right)$ were obtained.

\section{Discussion}

Inter-row cultivation and mowing were less efficient than chemical control without inter-row cultivation for controlling invasive grasses and for seedling development. Mowing did not control brachiaria as effectively as chemical control because individuals of this invasive fodder grass do not die after shoot cut. Indeed, throughout their evolutionary history, tropical grasses have developed adaptive strategies to withstand herbivory and grazing (Coughenour, 1985). Consequently, brachiaria mowing may prune rather than kill individuals, as glyphosate does. Hence, if mowing is used as a strategy for grass control in restoration plantings, the frequency of intervention must be increased in order to prevent brachiaria individuals from attaining enough biomass to heavily compete with tree seedlings, as observed by Sun and Dickson (1996).

Unfortunately, our study could not include a control treatment, in which grass cover and seedling development would be evaluated without inter-row cultivation, mowing or use of herbicides. We do not expect to infer that inter-row cultivation or mowing is an inefficient method for grass control and should not be used at all, for example, some restoration projects continuously cultivate between rows, which may be a more efficient technique for controlling invasive grasses but it was not done in the present study.

Even when considering pumpkin production, glyphosate use before sowing would be necessary for supporting a favorable yield. Pumpkin production of $341 \mathrm{~kg}$ ha $^{-1}$ in treatment 3 of this study is minute vis-a-vis the average production in intensive monocultures, were it ranges from 12 to $20 \mathrm{t} \mathrm{ha}^{-1}$ (Figueira, 2003). One must not expect that inter-row cultivation reach the same productivity patters as intensive monocultures, but we suggest that, if restoration practitioners wish to generate income with inter-row cultivation, priority should be given to the agricultural practices of the chosen culture and the planting of native tree seedlings should be adapted to these practices, and not the opposite. Also, considering that no difference was observed in the interrow cultivation of either pumpkin or crotalaria for grass cover and seedling development, we suggest, due to its yield, the cultivation of pumpkin or other crops of economic importance in restoration projects where chemical control of invasive grasses is not permitted.
Brachiaria and other invasive fodder grasses have been considered one of the most important biological barriers to restoring tropical forests worldwide /García-Orth and Martínez-Ramos, 2011; Ortega-Pieck et al., 2011, and references therein), and their effective control is essential to support the fast development of the forest under restoration (Campoe et al., 2010). As a result, we may have a trade-off between the use of alternative methods of grass control and the development of the forest community under restoration. Nevertheless, green manures reduced spontaneous grass coverage compared to control plots (Favero et al., 2001) and that species richness is reduced in natural regeneration by the use of herbicides (Pywell et al., 2010). Therefore, this dichotomy must be further investigated in order to provide non-chemical methods of grass control in restoration plantings, but with minimum efficiency levels; otherwise, although we may avoid the risks of soil and water contamination associated with herbicide use, we may fail to achieve a well-established native tree community in degraded sites if ineffective alternative methods of grass control are adopted.

\section{Acknowledgements}

The authors thank all "S.O.S. Mata Atlântica" staff, especially those from the "Centro de Experimentos Florestais de Itu" and two anonymous reviewers for the valuable comments on this manuscript. The Crotalaria breviflora seeds were kindly donated by the green manure seeds company "Piraí Sementes". We also thank Alaine Ball and Leama Ajaka for the English proofread.

\section{References}

Aide, T.M.; Zimmerman, J.K.; Herrera, L.; Rosario, M.; Serrano, M. 1995. Forest recovery in abandoned tropical pastures in Puerto Rico. Forest Ecology and Management 77: 77-86.

Ansley, R.J.; Castellano, M.J. 2006. Strategies for savanna restoration in the southern great plains: effects of fire and herbicides. Restoration Ecology 14: 420-428.

Baer, S.G. 2004. Herbicide and tillage effects on volunteer vegetation composition and diversity during reforestation. Restoration Ecology 12: 258-267.

Blanchoud, H.; Moreau-Guigon, E.; Farrugia, F.; Chevreuil, M.; Mouchel, J.M. 2007. Contribution by urban and agricultural pesticide uses to water contamination at the scale of the Marne watershed. Science of the Total Environment 375: 168-179.

Carlson, A.M.; Gorchov, D.L. 2004. Effects of herbicide on the invasive biennial Alliaria petiolata (Garlic Mustard) and initial responses of native plants in a southwestern Ohio forest. Restoration Ecology 12: 559-567.

Campoe, O.C.; Stape, J.L.; Mendes, J.C.T. 2010. Can intensive management accelerate the restoration of Brazil's Atlantic forests? Forest Ecology and Management 259: 1808-1814.

Chazdon, R.L. 2012. Beyond deforestation: restoring forests and ecosystem services on degraded lands. Science 320: 14581460 . 
Cornish, P.S.; Burgin, S. 2005. Residual effects of glyphosate herbicide in ecological restoration. Restoration Ecology 13: 695-702.

Coughenour, M.B. 1985. Graminoid responses to grazing by large herbivores: adaptations, exaptations, and interacting processes. Annals of the Missouri Botanical Garden 72: 852-863.

Favero, C.; Jucksch, I.; Alvarenga, R.C.; Costa, L.M. 2001. Modifications in the population of spontaneous plants in the presence of green manure. Pesquisa Agropecuária Brasileira 36: 1355-1362. (in Portuguese, with abstract in English).

Figueira, A.R.F. 2003. Novo Manual de Olericultura = The New Manual of Olericulture. Universidade Federal de Viçosa, Viçosa, MG, Brazil (in Portuguese).

Florentine, S.K.; Westbrooke, M.E. 2004. Restoration on abandoned tropical pasturelands - do we know enough? Journal for Nature Conservation 12: 85-94.

García-Orth, X.; Martínez-Ramos, M. 2011. Isolated tres and grass removal improve performance of transplanted Trema micrantha (L.) Blume (Cannabaceae) saplings in tropical pastures. Restoration Ecology 19: 24-34.

Holl, K.D. 1999. Factors limiting tropical rain forest regeneration in abandoned pasture: seed rain, seed germination, microclimate and soil. Biotropica 31: 229-242.

Hooper, E.; Legendre, P.; Condit, R. 2005. Barriers to forest regeneration of deforested and abandoned lands in Panamá. Journal of Applied Ecology 42: 1165-1174.

Nair, P.K.R.; Hernandes, L.C.M.; Wambugu, P.N. 1984. Multipurpose leguminous trees and shrubs for agroforestry. Agroforestry Systems 2: 145-163.

Ortega-Pieck, A.; López-Barrera, F.; Ramírez-Marcial, N.; GarcíaFranco, J.G. 2011. Early seedling establishment of two tropical montane cloud forest tree species: the role of native and exotic grasses. Forest Ecology and Management 261: 1336-1343.
Pywell, R.F.; Hayes, M.J.; Tallowin, J.B.; Walker, K.J.; Meek, W.R.; Carvell, C.; Warman, L.A.; Bullock, J.M. 2010. Minimizing environmental impacts of grassland weed management: can Cirsium arvense be controlled without herbicides? Grass and Forage Science 65: 159-174.

Relyea, R.A. 2005. The impact of insecticides and herbicides on the biodiversity and productivity of aquatic communities. Ecological Applications 15: 618-627

Rodrigues, R.R.; Gandolfi, S.; Nave, A.G.; Aronson, J.; Barreto, T.E.; Vidal, C.Y.; Brancalion, P.H.S. 2011. Large-scale ecological restoration of high-diversity tropical forests in SE Brazil. Forest Ecology and Management 261: 1605-1613.

Rodrigues, R.R.; Lima, R.A.F.; Gandolfi, S.; Nave, A.G. 2009. On restoration of high diversity forests: 30 years of experiences in the Brazilian Atlantic Forest. Biological Conservation 142: 1242-1251.

Sun, D.; Dickson, G.R. 1996. The competition effect of brachiaria decumbens on the early growth of direct-seeded trees of Alphitonia petriei in tropical north Australia. Biotropica 28: 272-276.

Thompson, D.G.; Solomon, K.R.; Wojtaszek, B.F.; Edginton, A.N.; Stephenson, G.R. 2006. The impact of insecticides and herbicides on the biodiversity and productivity of aquatic communities. Ecological applications 16: 2022-2027.

Vieira, D.L.M.; Holl, K.D.; Peneireiro, F.M. 2009. AgroSuccessional restoration as a strategy to facilitate tropical forest recovery. Restoration Ecology 17: 451-459.

Walker, G.E.; Morey, B.G. 1999. Effect of brassica and weed manures on abundance of Tylenchulus semipenetrans and fungi in citrus orchard soil. Australian Journal of Experimental Agriculture 39: 65-72.

Wuethrich, B. 2007. Reconstructing Brazil's Atlantic rainforest. Science 315: 1070-1072. 